\title{
ГРАМАТИКА
}

УДК 811.161.2’367.335

О. О. Полозова

\section{ІМПЛІЦИНИЙ ДИКТУМ ЯК ЧИННИК ФОРМУВАННЯ КІЛЬКІСНО АСИМЕТРИЧНИХ СКЛАДНИХ СПОЛУЧНИКОВИХ РЕЧЕНЬ}

У статті на підставі з'ясування сутності категорії формально-змістової асиметрії на рівні складного сполучникового речення виявлено й схарактеризовано кількісно асиметричні конструкиї з імпліцитним диктумом, окреслено чинники й механізми творення кількісної асиметрії в складних сполучникових реченнях; схарактеризовано інтра- та екстралінгвальні чинники, що зумовлюють виникнення невідповідності синтаксичної форми й змісту; простежено когнітивно-прагматичні причини формування кількісно асиметричних речень з імпліичитним диктумом.

Ключові слова: складносурядне речення, складнопідрядне речення, кількісна формально-змістова асиметрія, імплічитний диктум, екстралінгвальний чинник.

Polozova O. Implicit Dictum as a Factor in the Formation of Quantitatively Asymmetric Complex Conjunctive Sentences. The relevance of the study is due to the need to generalize information about quantitatively asymmetric complex conjunctive sentences with formally unexpressed (implicit) dictum in the Ukrainian language on the basis of modern ideas about the mismatch of form and content in the structure of complex syntactic constructions.

The aim of the research is to determine the range of complex conjunctive sentences of the modern Ukrainian language with implicit dictum and to clarify the intralingual and extralingual factors of formation of quantitative formal-semantic asymmetry in them. The subject of the research is complex conjunctive sentences of the modern Ukrainian language. The main objectives of the study are: to identify and characterize quantitatively asymmetric complex conjunctive sentences with implicit dictum; to outline the factors and mechanisms of creating formal-semantic quantitative asymmetry in complex conjunctive sentences; to trace the cognitive-pragmatic reasons for the formation of quantitatively asymmetric sentences with implicit dictum.

As a result of this scientific research it was found that the reduction of the dictum component occurs in multicomponent constructions, on the basis of which compound sentences with conjunctions a mo, a не mо, aлe and complex sentences 
with conjunctions як, як коли, ніж коли / якщо etc appear. When classifying these constructions, the formal feature (the nature of the connector) should be taken into account. The linguistic factors that cause the appearance of quantitatively asymmetric constructions with implicit dictum are the specifics of the means of communication and the lexical-semantic content of predicative parts. Among the extralingual reasons for the formation of quantitatively asymmetric complex conjunctions, in particular, is the speaker's ability to frame perception of complex situations of reality.

Keywords: compound sentence, complex sentence, quantitative formal-semantic asymmetry, implicit dictum, extralingual factor.

\section{Вступ}

Кількісна асиметрія проявляється в порушенні типового для складного сполучникового речення (як двопредикативних / двопропозитивних структур) співвідношення між формою та змістом. Одним з різновидів таких структур є імпліцитні складні сполучникові речення, що є семантичними аналогами багатокомпонентних конструкцій. Поява таких речень спричинена здатністю людини сприймати типові ситуації дійсності як фреймові структури, для кожної 3 яких у мові витворилися питомі синтаксичні побудови, що можуть унаслідок своєї типовості видозмінюватися відповідно до прагматичних інтенцій комунікантів. За мовною природою такі конструкції $€$ найчастіше результатом синтаксичної деривації. Тому в процесі їх аналізу особливого значення набуває чітке дотримання принципу розмежування категорій диктуму (диктумної пропозиції), тобто об’єктивного змісту речення, і модусу (модусної пропозиції), тобто відображення “несубстанційної” дійсності, психічної реальності, рефлексії мовця з приводу іншої події (Балли, 1955: 44), та врахування специфіки сполучних засобів (як логічних пропозицій).

На узагальнений опис у вітчизняному мовознавстві кількісно асиметричні конструкції до цього часу не здобулися, причину чого можна вбачати в тому, що чимало таких складних сполучникових речень принагідно були проаналізовані в межах описів окремих груп складних речень (М. С. Заоборна (Заоборна, 1996), С. В. Ломакович (Ломакович, 1993), Л. В. Шитик (Шитик, 2014) та ін.) або ж згадані в граматиках (I. Р. Вихованець (Вихованець, 1993), А. П. Загнітко (Загнітко, 2001), I. I. Слинько (Слинько, Гуйванюк, \& Кобилянська, 1994) та ін.) і при цьому отримували ту чи ту наукову інтерпретацію, яка загалом видавалася задовільною. Утім такий несистемний підхід 
до кількісно асиметричних складних сполучникових речень української мови не можна вважати виправданим передусім 3 огляду на те, що неврахування їхньої специфічної конструктивної будови тягне за собою в деяких випадках їх сумнівну класифікаційну номінацію, зумовлює необхідність подальшого аналізу у відповідному ракурсі й визначає актуальність дослідження.

Мета цієї наукової розвідки - визначення кола складних сполучникових речень сучасної української мови з імпліцитним диктумом, з'ясування інтра- та екстралінгвальних чинників формування в них кількісної формально-змістової асиметрії. Предметом дослідження $\epsilon$ складні сполучникові речення сучасної української мови. Основні завданнями дослідження: 1) виявити й схарактеризувати кількісно асиметричні складні сполучникові речення з імпліцитним диктумом; 2) окреслити чинники й механізми творення формально-змістової асиметрії в складних сполучникових реченнях; 3) простежити когнітивно-прагматичні причини формування кількісно асиметричних речень з імпліцитним диктумом.

\section{Методи дослідження}

У роботі застосовуємо низку методів дослідження, 3-поміж яких описовий - для вивчення й інвентаризації випадків кількісної формально-змістової асиметрії в системі складних сполучникових речень, трансформаційного аналізу - для імплікації семантичного компонента, що формально не виражений, метод вибірки залучено для відбору фактичного матеріалу, контекстного аналізу (для простеження впливу внутрішньо- й зовнішньореченнєвого контексту на зміст складних сполучникових речень).

\section{Виклад основного матеріалу}

У реченні як основній одиниці синтаксису більшою мірою, ніж в інших одиницях мови (фонемі, морфемі, слові), відбивається позамовна дійсність. У ньому передаються зв’язки й відношення між поняттями, предметами, явищами навколишнього світу, які сприймаються людиною та шукають свого вербалізованого вияву. При цьому синтаксичні структури на тлі інших мовних одиниць характеризуються “твердістю”, тобто своїм досить обмеженим арсеналом вони фактично відбивають типові моделі дійсності. Ця типовість 
спричиняє до того, що синтаксична форма в процесі функціонування мови розвивається і стає зручнішою та ефективнішою, тобто прагне до більш компактних, економних способів вираження. Одним із засобів ефективізації є позбавлення синтаксичних конструкцій від словесної надмірності. У багатьох мовленнєвих ситуаціях такі властивості синтаксичних одиниць, як смислова ємність і водночас словесна стислість, виявляються не лише бажаними, а й необхідними. Як зазначають дослідники, з-поміж найбільш частих і типових способів синтаксичного перетворення фрази чи ії фрагментів є скорочення поверхово-синтаксичної структури за одночасного ускладнення, “ущільнення" інформації, що міститься в ній. Це явище в лінгвістиці має різні назви: еліпсис, компресія, стягнення, згортання, універбація тощо (Балли, 1955: 44-65; Загнітко, 2001: 303-308; Колосова, 1980: 48 51; Кульбабська, 2011: 132-135). Завдяки цим прийомам випадають із логічно розгорнутих конструкцій надлишкові словесні компоненти й виникає синтаксичне об'єднання складників, що повністю зберігають семантико-синтаксичні значення вихідних, глибинних структур (Гизатулин, 2001: 75). Внутрішні логіко-граматичні та семантичні зв'язки виявляються імпліцитними, а формальна структура - згорнутою, тобто кількість предикативних одиниць у ній не відповідає кількості семантично передбачених компонентів модусної чи диктумної природи. Т. А. Колосова запропонувала для таких випадків компресії в складному реченні термін “імпліцитні конструкції”, під якими розуміє такі побудови, де окремі компоненти змісту не знаходять спеціального вираження за допомогою формальних мовних засобів, але висловлення залишається автосемантичним та інформативно достатнім без звернення до конситуації, оскільки вербалізовані ланки мовби вбирають у себе семантику невербалізованих (Колосова, 1980: 50).

Як правило, у реченні зникає внутрішня ланка конструкції за збереження крайніх, але саме в них і зберігається потрібне мовцеві значення.

Під час дослідження було з'ясовано, що в українській мові диктумний компонент елімінується в складносурядних реченнях зі сполучниками а то, а не то, але, а в складнопідрядних - у порівняльних, а також у конструкціях зі сполуками на зразок як коли, як коли б, ніж коли, ніж якщо, ніж якби, ніби щоб та з умовними сполучниками. 
Складносурядні речення. Досить поширеними в мовленні $€$ складносурядні речення зі сполучником а то на зразок Тримайтеся за стільия, а то зараз впадете («Українська правда», 13.01.2010); Зараз мені злазь, а то я полізу та сам тебе стягну, та всиплю тобі сотню різок (І. Нечуй-Левицький). Щодо їх кваліфікації дослідники неодностайні: одні визначають ї складносурядними з протиставно-умовними відношеннями (Виноградов, 1954: 195), інші - складносурядними розділовими, зазначаючи при цьому, що в них можуть передаватися й інші відтінки значення - 'інакше', 'насправді', 'бо' (Слинько, Гуйванюк, \& Кобилянська, 1994: 623). В. А. Бєлошапкова визначає такі конструкції як речення альтернативної мотивації, указуючи, що в них виражається вид причинової зумовленості - відношення мотивації, що засновані не на встановленні безпосереднього зв'язку між двома подіями, а на припущенні як необхідному з'єднувальному ланцюгові ймовірної третьої, прямо не названої в реченні події, яка могла б реалізуватися в разі нездійснення події, названої в першій частині (Белошапкова, 1970: 14). На противагу цим позиціям К. Г. Городенська сполучник а то визначає як підрядний, що виражає причинові семантико-синтаксичні відношення, поєднуючи підрядну з головною частиною складнопідрядного речення підрядним детермінантним зв'язком (Городенська, 2007: 44), із чим аж ніяк не можна погодитися, у чому переконує погляд на ці конструкції як на кількісно асиметричні.

Речення альтернативної мотивації характеризуються тим, що одна з предикативних частин, що стоїть після сполучника, називає небажану подію, яка 6 могла реалізуватися, якщо б не подія препозитивної предикативної частини, напр.: Ходім до матері, а то ще дадуть прочухана (М. Старицький). Водночас у мові $€$ і такі речення, у яких друга предикативна одиниця називає бажану з погляду мовця подію, напр.: Новий врожай далеко, а то б хоч колосок сирий підживив (В. Барка); Не п'ю вранці пива, а то б залюбки (В. Шкляр).

Т. А. Колосова, досліджуючи речення зі сполучником а mо, зауважувала, що під час логіко-семантичного аналізу таких висловлень необхідно враховувати невербалізований ланцюг, що має семантику події в чомусь протилежної тій, яка названа першим компонентом, відповідно, на думку синтаксистки, такі двокомпонентні речення є імпліцитними варіантами експліцитних трикомпонентних конструкцій 
(Колосова, 1980: 103), пор.: Ходім до матері, бо якщо не підемо, то ще дадуть прочухана; ...вона повинна вміти добре готувати, прибирати, а також подалі “ховати” свій характер, бо якщо иьвого не робити, то ніхто не візъме ії заміж. Варто погодитися з дослідницею в тому, що подібні конструкції $є$ імпліцитними побудовами, але водночас необхідно звернути увагу на те, що в процесі їх інтерпретації вона залишає поза увагою семантику сполучника $a$, який $€$ сигналом зіставлення двох ситуацій: мети й умови. Отже, ці двокомпонентні конструкції все ж видається більш логічним розглядати як імпліцитні варіанти не трикомпонентних (як це стверджує Т. А. Колосова), а чотирикомпонентних речень, пор.: Ходім до матері, щцоб не дали прочухана, а якщо не підемо, то дадуть прочухана; ...вона повинна вміти добре готувати, прибирати, а також подалі “ховати” свій характер, щоб ії взяли заміж, а якщо цього не робити, то ніхто не візвме ії заміж. У цих висловленнях сполучник а залишається ядром конструкції і поєднує сурядним зв'язком зіставлення багатокомпонентне речення, перша предикативна конструкція якого є бажаним наслідком, тобто метою мовця (Ходім до матері, щцоб не дала прочухана; ...вона повинна вміти добре готувати, прибирати, а також подалі “ховати" свій характер, щзоб їі взяли заміж), а в другій частині моделюється ситуація, яка може виникнути за умови, якщо перша не буде реалізована (якщо не підемо, то дасть прочухана; якщо цього не робити, то ніхто не візвме ії заміж). Отже, формально ці конструкції складаються 3 двох предикативних частин, але на семантичному рівні містять чотири пропозиції.

У розгорнутому вигляді такі конструкції майже не вживаються, але іноді мовець використовує й експліцитний варіант для забезпечення надійності сприйняття висловлення адресатом, напр.: Дітки, потрібно слухатися батьків, щцоб Святий Миколай поклав вам під подушку иукерки, а як не будете, то він покладе вам не смаколики, а різочку (з телепередачі). Уживання розгорнутої, експліцитної конструкції пояснюється тим, що автор звертається до дітей і намагається передати інформацію в більш доступній і зрозумілій формі. У текстах також трапляються розгорнуті конструкції, у яких предикативні одиниці частково тотожні, напр.: Складіть грабік, щоб дійсно встигнути зробити реальну роботу, а якщо не сплануєте ранок, то ви не будете продуктивні ${ }^{1}$.

\footnotetext{
${ }^{1}$ Facebook. Узято 3: https://www.facebook.com.
} 
До речень $з$ імпліцитним диктумним компонентом належать також конструкції з протиставним сполучником але, перша частина яких містить дієслово умовного способу, а друга має семантику реальної події, напр.: Палестинська держава могла б бути проголошеною ще на початку 1980-х років, але Арафат не був зацікавлений у встановленні миру («Сучасність», 2004, № 11). Ця двокомпонентна конструкція є імпліцитним варіантом чотирикомпонентного речення. Підставою для можливості розгортання є умовний спосіб дієслова в першій частині двокомпонентного речення зі сполучником але. На думку Т. А. Колосової, якщо форма умовного способу дієслова має гіпотетичне значення, то вона є синтаксично зв'язаною, оскільки означає зумовлену дію і не може бути інформативно достатньою без інших ланок, які вказують на умову. Не випадково основною функцією умовного способу є функція присудка в підрядному реченні зі сполучником якщзо та його еквівалентами. Використання умовного способу визначає семантичну й граматичну незавершеність головної частини, тому вона завжди передбачає наявність підрядної частини (Колосова, 1980: 129). Наприклад, у реченні типу Я зайшов би, але в мене часу нема (з усн. мовл.) обов'язковим є присудок умовного способу в першій частині, що позначає нереалізовану ситуацію, яка могла $б$ відбутися за певних умов. Як зазначалось вище, умовний спосіб може вживатися лише в тих предикативних одиницях, які позначають зумовлену подію, і в яких названа подія, що $є$ ірреальною умовою.

У наведених реченнях перша частина є компонентом складного речення, однак сполучник але не належить до умовних, що дає підстави для припущення, що ці двокомпонентні речення $є$ імпліцитними варіантами чотирикомпонентних конструкцій, пор.: Якби в мене був час, то я зайшов би, але в мене часу нема, так що я не зайду; Якби Арафат був зацікавлений у встановленні миру, то Палестинська держава могла б бути проголоченою ще на початку 1980-х років, але Арафат не був зацікавлений у встановленні миру, так що Палестинська держава не була проголошена на початку 1980-х років. Отже, як показують приклади, сполучник але протиставляє зміст складнопідрядного умовного та складнопідрядного наслідкового речень.

Під час розгортання імпліцитних двокомпонентних речень у чотирикомпонентні експліцитні конструкції їхні частини дублюються, 
але із запереченням. Такі конструкції, які б повністю зберігали тотожність лексичних одиниць і відрізнялися б лише наявністю заперечення, у текстах майже не трапляються. Зазвичай у подібних реченнях предикативні одиниці частково тотожні, напр.: Якби ці візити змічнювали міжнародне становище Украӥни, приносили в нашу державу нові іноземні інвестицї, напевно, таку активність варто було б вітати, але інвестицій ми поки не бачимо, так що візити залишаються просто візитами («Сучасність», 2005, № 10).

Отже, аналіз мовного матеріалу показав, що в текстах функціонують як експліцитні чотирикомпонентні конструкції, так й імпліцитні двокомпонентні речення, у яких вербалізовані друга й третя ланки логічного ланцюга, але вони $є$ інформативно достатніми й без звернення до контексту.

Складнопідрядні речення. Проаналізований мовний матеріал засвідчує, що серед конструкцій із формально невираженим диктумним компонентом $€$ й складнопідрядні, зокрема порівняльні, двокомпонентні складні конструкції, підрядна частина яких приєднується сполуками на зразок: як коли, як коли б, ніж коли, ніж якщь, ніж якби, ніби щоб (у таких реченнях дві предикативні частини відповідають трьом пропозиціям), а також двокомпонентні конструкції, семантично тотожні експліцитним чотирикомпонентним висловленням з умовними сполучниками. На ці конструкції свого часу звертали увагу Т. А. Колосова та М. С. Заоборна (Колосова, 1980; Заоборна, 1996).

У порівняльних складнопідрядних реченнях може формуватись імпліцитний, невербалізований зміст диктумного характеру. У сучасній українській мові функціонує декілька типів порівняльних конструкцій, у яких кількість пропозицій не відповідає кількості предикативних частин. 1. Конструкції, які відображають порівняння двох складних каузативних ситуацій дійсності. 3 них та ситуація, що репрезентована в підрядній частині, постає як еталонна. Якщо ж у головній частині експлікуються і ситуація-каузатор, і ситуація, що каузується, то підрядна частина експлікує лише ситуацію, яка каузує певний стан речей, що в структурі порівняльної конструкції виражений імпліцитно. Наприклад, під час його вербалізації конструкція на зразок Христі новина та не давала спокою, як миша скребеться в куточку (Панас Мирний) може бути інтерпретована як Христі новина не давала спокою, як не дає комусь спокою те, що миша 
скребеться в куточку. У головній частині “новина” каузує “неспокій Христі"; у підрядній частині “мища скребеться в куточку" каузує “неспокій когось". 2. Конструкції з імпліцитним еталоном порівняння, зміст якого однотипний зі змістом головної частини. При цьому імпліцитна ситуація-еталон може усвідомлюватися як певні відчуття, що $є$ наслідком того стану речей, який наведений у підрядній частині, напр.: Пожар революиій тріскоче, як рвуться сорочка і прапор (О. Забужко), пор.: Пожар револючій тріскоче, я тріскоче тоді, коли рвуться сорочка і прапор; Скрегоче ключ у замку, як ото вітер уночі ворота відчиняє (Гр. Тютюник), пор.: Скрегоче ключ у замку, як скрегоче тоді, коли вітер уночі ворота відчиняє (Заоборна, 1996: 128-129).

До речень з імпліцитним диктумним компонентом належать двокомпонентні речення, підрядна частина яких починається порівняльними сполучниками як, ніж, ніби в поєднанні з іншими підрядними сполучниками коли, коли б, якщз, якби, напр.: Лищ вишневий ивіт з гробів летів за мною, як коли б тим ивітом сестра і мама просили, аби я не йшов (В. Стефаник); Я зачудовано стежив за кожним ї̈ рухом, бо, коли жінка зодягається, ие не менш иікаво, ніж коли вона той одяг знімає (В. Шкляр). Граматична природа таких сполук, як ніж коли, як коли, ніж якщо та подібних трактується по-різному. Дехто з дослідників уважає такі сполуки складеними порівняльними сполучниками, тобто однією одиницею, дехто - послідовністю двох сполучників (Колосова, 1980: 36). На думку Т. А. Колосової, у тих випадках, коли підрядна частина приєднується до препозитивної головної частини двома контактними сполучниками, спостерігаємо компресію двох послідовно підрядних частин, першу з яких, поновлювану з препозитивної головної частини, представлено лише порівняльним сполучником (Колосова, 1980: 39). Слушність цієї думки доводить М. С. Заоборна. Дослідниця звертає увагу на те, що в мові $є$ речення зі сполучниковою єдністю як коли б, де кожен з елементів указує на певний тип відношень: як - порівняння; коли - умова; би - гіпотетичність, напр.: Іван та й здоймив руки вгору, як коли би мав гадку злетіти (В. Стефаник), пор.: Іван та й здоймив руки вгору, як зробив би ие, коли б мав гадку злетіти (Заоборна, 1996: 135). Отже, двокомпонентні складні речення зі сполучниковими єдностями ніж коли, як коли, ніж якщз та ін. можна вважати імпліцитними варіантами семантично тотожних трикомпонентних (експліцитних) складних речень, пор.: ... Лиш 
вишневий ивіт з гробів летів за мною, як летів би, коли б тим ивітом сестра і мама просили, аби я не йшов; ...коли жінка зодягається, ие не менш цікаво, ніж буває цікаво тоді, коли вона той одяг знімає.

Можливість розгортання двокомпонентних імпліцитних речень із контактними сполучниками підтверджує той факт, що в мові $\epsilon$ й розгорнуті експліцитні конструкції, напр.: Вона подивилася на нього, як дивилась тоді, коли він уперще їі побачив (Д. Корній). Особливістю експліцитних конструкцій є лексична тотожність предикатів головної й підрядної частин.

Наведені приклади доводять, що в усіх двокомпонентних реченнях послідовність контактних сполучників (ніж коли, як коли, ніж якщо, ніж якби, ніби щоб) не створює єдиної одиниці. Імпліцитні висловлення з названими сполуками мають семантику трикомпонентних експліцитних конструкцій, у яких між контактними скріпами есплікується предикативна одиниця, що є семантично тотожною першій (препозитивній) предикативній одиниці (Колосова, 1980: 84). Усі подібні імпліцитні конструкції є семантично автономними, зрозумілими без контексту, оскільки вербалізовані компоненти висловлення ніби розподіляють між собою семантику невербалізованої ланки.

Крім наведених типів підрядних речень з імпліцитним компонентом, проаналізований мовний матеріал засвідчив, що в українській мові функціонують також двокомпонентні умовні речення, тотожні чотирикомпонентним конструкціям, напр.: Якби в останній момент не відвернув голову, миле дитя скалічило б дурнуватого дядька (В. Слапчук). Такі конструкції, у яких хоча 6 одна з предикативних частин має дієслово-присудок у формі умовного способу, можуть бути розгорнуті в семантично тотожні чотирикомпонентні висловлення. У таких реченнях вербалізовані перші дві ланки логічного ланцюга, а дві останні домислюються під час декодування тексту, пор.: Якби в останній момент не відвернув голову, то миле дитя скалічило б дурнуватого дядька, але він відвернув, тому дитя його не скалічило. Такі речення ірреальної умови фіксують умовний зв'язок між двома подіями, кожна з яких $є$ такою, що не відповідає дійсності, тобто в них названі не реальні, а уявні ситуації, які за своєю семантикою протилежні фактичному стану речей. Тобто, з одного боку, у таких реченнях повідомляється про зв'язок між подіями, яких не існує, а з другого, - у них міститься інформація про реальну дійсність (Кулькова, 1994: 149). 
Зіставлення імпліцитного й експліцитного варіантів проаналізованих речень показує, що в першому вербалізовані два компоненти, а третя й четверта ланки логічного ланцюга не мають реального вираження, хоча їхня семантика всотана компонентами, вираженими за допомогою формальних засобів мови, вони домислюються учасниками комунікації завдяки фоновим знанням.

Експліцитні чотирикомпонентні конструкції в текстах майже не трапляються, більш поширеними є речення, у яких третя й четверта предикативні одиниці мають інше, порівняно з першими, лексичне наповнення, напр.: I коли б вони обоє примирилися із несприйнятним одне одному, ніякої трагедіі б не сталося. Але обоє були закляті, тимто їхя війна й протривала так довго (В. Шевчук).

3 погляду лінгвокогнітивного підходу здатність мовців творити й відповідно сприймати та розуміти різноманітні вияви семантичних зрушень, синтаксичних зміщень і стягнень, які можуть у складних сполучникових реченнях бути доволі складними, можна пояснити тим, що 1) усі ці перетворення не настільки індивідуальні й за ними приховуються зразки, які мають певні експліцитні ознаки, і те, що звичайний носій мови розпізнає ці висловлення, свідчить, що в його свідомості працюють апробовані механізми аналізу й синтезу таких фраз; 2) мовна свідомість дуже гнучка й має здатність до апроксимації, до роботи з нечіткими множинами, до прийняття приблизних рішень, тому коли слухач сприймає щось складне, він намагається знайти бодай якісь відповідники у світі референтів, спираючись на попередній життєвий досвід (Норман, 2012: 165-166). Фактично в цьому разі йдеться про латентні, приховані процеси, що протікають у внутрішньому мовленні, а на виході виникають стиснуті смислові конфігурації, які в мовній свідомості можуть із часом “легалізуватися” настільки, що спокуса їх розгортати, розшифровувати їх дериваційну природу навіть не виникає в мовця (Норман, 2012: 153).

3 лінгвопрагматичного ж погляду феномен імплікації можна пояснити рефлексивністю мовленнєвої діяльності, яку здійснює мовець. У конкретних комунікативних ситуаціях комунікант, який може обирати будь-яку з конструкцій - експліцитну чи імпліцитну, що закріплена в його мовній свідомості як знак для типової моделі дійсності, типового фрейму, керується факторами, що структурують конкретну ситуацію спілкування чи конкретний жанр, зокрема 
своїми уявленнями про тип співрозмовника, прагматичною інтенцією в конкретному комунікативному акті чи ході як елементах тактики й стратегії. Для обгрунтування цієї думки показовими можуть бути такі дві комунікативні ситуації.

1. Парубки обступили Лавріна навкруги.

- Я не бієвський. Я прийшов в Бієвиі недавно і шукаю собі роботи, - обізвався Лаврін.

- Ого-го, добрий робітник! Роботи не знайшов, а на вулицю зараз дорогу знайшов! - крикнув другий парубок.

- Коли хочеш з нами гуляти та до наших дівчат ходить, то став нам могорича, а то ми тобі киями покажемо дорогу з нашої вулииі.

Лаврін знав парубоцький звичай і повів усю парубочу ватагу в шинок. Він поставив їм могорича й вже в згоді з ними вернувся на вулицю (I. Нечуй-Левицький);

2. - Om і все, - баба розплюшила очі, накрила долонею змішане з воском зілля. - А тепер слухай. Душа твоя чиста розірвана навпіл, i не знаєи ти, шьо добре, а шьо зле. А як того не розумієш, то й бредеш навпростець, хоч шляхи самі під ноги просяться. Ти дивишся навкруги - оие діло нібито добре, а придивляєшся - у багнюиі воно втопло. I далі бредеш без кіния і краю. І ось - знову багнюка. Ти руку простягла - та ні, иее ж чисте озеро. А всі навкруги - сліпі! Сліпі й кричать тобі: «Багнюка! Багнюка!» А ти оглухни! Оглухни, дитино, бо якия ні, то брести тобі крізь життя навпростець до скону і изастя не мати.

Баба замовкла, зиркнула на Катерину спідлоба (Люко Дашвар).

У наведених прикладах виділені речення мовці обирають для вираження подібного прагматичного змісту, а саме попередження про настання негативних наслідків (погроза й пророцтво). Водночас мовець ситуації 1 обирає згорнуту конструкцію: Коли хочеш з нами гуляmи та до наших дівчат ходить, то став нам могорича, а то ми тобі киями покажемо дорогу з нашої вулииі (= Став нам могорича, шьоб ми не показали дорогу киями, а якшьо не поставищ, то ми тоді киями покажемо дорогу...), а мовець ситуації 2 - експліцитну: Оглухни, дитино, бо якшьо ні, то брести тобі крізь життя навпростеи, до скону i шзастя не мати (= Оглухни, дитино, а то брести тобі крізь життя навпростець до скону $і$ щастя не мати). Обидва мовці в конкретних 
ситуаціях могли скористатися економним варіантом, однак лише перший обрав його, у такий спосіб деактуалізувавши фрейм інформування про умову настання в майбутньому негативного наслідку (інтенція турботливості). Очевидно, у цьому разі для мовця турбота про співрозмовника є не важливою, натомість значущою виявляється вказівка на негативний наслідок, а отже, більш потужний сигнал співрозмовникові на необхідність виконання дії, указаної в першій предикативній частині. I навпаки, у ситуації реалізації комунікативного жанру ворожіння (ситуація 2), для мовця (ворожка) украй необхідним є актуалізація тієї умови, невиконання якої спричинить настання небажаного для співрозмовника (дівчини) наслідку. При цьому в першій ситуації пресупозицією, що вможливлює редукцію на поверховому рівні умовного компонента синтаксичної конструкції, $€$ розуміння мовцем і співрозмовником своїх статусів (мовець - місцевий, співрозмовник - з іншого села), а отже, визнання ними обома можливості заподіяння одним шкоди іншому. Тоді як у другому випадку ворожка має розгортати умовний компонент, бо пресупозиція про істинність ії слів може розглядатися дівчиною не як наявна, саме тому ворожка забезпечує вербалізованим умовним компонентом (якщ, нi) перекладання відповідальності із себе на дівчину, припускаючи, що це матиме додатковий вплив на сприйняття тією вагомості їі передбачення. У такому розрізі варто дослухатися до думки С. Димитрової, яка стверджує «контраст між тим, що стверджується, і тим, що пресупозується, є тією основою, на якій мовець здійснює процес актуалізації речення в дискурсі. Його (мовця. - О. П.) уявлення про ступінь обізнаності адресата можна розглядати як модель можливого світу адресата в голові мовця. Ця модель підказує мовцю конкретні рішення поверхових структур речень. Намагаючись говорити так, щоб бути зрозумілим, мовець здійснює актуалізацію речень у дискурсі в кінцевому підсумку в такий спосіб, щоб кожне речення сприймалося слухачем як умовний знак строго визначеного набору пресупозицій» (Димитрова, 1985: 544).

Отже, у процесі аналізу імпліцитних синтаксичних одиниць важливим є виявлення як причин, що актуалізують саме ці конструкції, а не їні розгорнуті варіанти (синоніми) в мовленнєвих практиках, так і мовних чинників та механізмів формування згорнутих конструкцій із їхнім специфічним семантичним потенціалом. 


\section{Висновки}

Отже, аналіз досліджуваного матеріалу дає змогу стверджувати, що редукція диктумного компонента відбувається в багатокомпонентних конструкціях, на основі яких виникають складносурядні речення зі сполучниками $а$ mо, а не то, але й складнопідрядні - зі сполучниками як, як коли, ніж коли / якщо та ін. У процесі класифікації цих конструкцій варто брати до уваги формальну ознаку (характер сполучника).

Багатокомпонентні й двокомпонентні конструкції синхронно співіснують у мові з тенденцією до більш широкого вживання в мовленнєвих ситуаціях стягнених конструкцій як наслідку дії загальномовної тенденції до економії мовленнєвих зусиль.

Поява кількісно асиметричних складних сполучникових речень 3 імпліцитним диктумом спричинена здатністю людини сприймати типові ситуації дійсності як фреймові структури, для кожної з яких у мові витворилися питомі синтаксичні побудови, що можуть унаслідок своєї типовості видозмінюватися відповідно до прагматичних інтенцій комунікативних ситуацій. За своєю мовною природою такі конструкції є результатом синтаксичної деривації.

Перспективою досліджень $є$ подальше вивчення складних сполучникових речень і виявлення кола асиметричних конструкцій в українській мові, а також інтра- та екстралінгвальні факторів, що зумовлюють виникнення невідповідності синтаксичної форми своєму ядерному змісту.

\section{ЛІТЕРАТУРА}

1. Балли, Ш. (1955). Общцая лингвистика и вопросы франиузского языка. Москва: Иностр. лит-ра. 2. Белошапкова, В. А. (1970). Предложения альтернативной мотивации в современном русском языке. В Исследования по современному русскому языку (с. 13-32). Москва: Изд-во Моск. ун-та. 3. Виноградов, В. В. (Ред.). (1954). Грамматика русского языка. (Т. 2). Москва: Изд-во АН СССР. 4. Вихованець, І. Р. (1993). Граматика української мови. Синтаксис. Київ: Либідь. 5. Гизатулин, С. Л. (2001). Семантическая экономия и избыточность в речи. Филологические науки, 2, 75-84. 6. Городенська, К. (2007). Граматичний словник української мови: Сполучники. Херсон: ХДУ. 7. Димитрова, С. (1985). Актуализация предложения и ее зависимость от степени осведомленности адресата. В Новое в зарубежной лингвистике. Современная зарубженая русистика. (Вып. 15). (с. 535-546). Москва: Прогресс. 8. Загнітко, А. П. (2001). Теоретична граматика української мови: Синтаксис. Донецьк: ДонНУ. 9. Заоборна, М. С. (1996). Складнопідрядні порівняльні речення в сучасній українській мові. (Дис. ...канд. філол. наук). Тернопіль: Терноп. держ. пед інст. 
10 Колосова, Т. А. (1980). Русские сложные предложения асимметричной структуры. Воронеж: Изд-во Воронеж. ун-та. 11. Кульбабська, О. В. (2011). Вторинна предикація y простому реченні. Чернівці: Чернів. нац. ун-т. 12. Кулькова, Р. А. (1994). Семантические типы предложений с союзом Если бы. Системный анализ значимых единии, руского языка. Смысловые типь предложений. (Ч. І). (с. 149-156). Красноярск: Краснояр. гос. ун-т. 13. Ломакович, С. В. (1993). Займенниково-співвідносні речення в сучасній українській мові. (Дис. ...д-ра філол. наук). Тернопіль: Терноп. держ. пед інст. 14. Норман, Б. Ю. (2013). Когнитивный синтаксис русского языка. Москва: ФЛИНТА. 15. Слинько, I. І., Гуйванюк, Н. В., \& Кобилянська, М. Ф. (1994). Синтаксис сучасної української мови: Проблемні питання. Київ: Вища шк. 16. Шитик, Л. (2014). Синхронна перехідність синтаксичних одиниць в украӥнській літературній мові. Черкаси: Вид. Чабаненко Ю. А.

\section{REFERENCES}

1. Balli, Sh. (1955). Obshhaya lingvistika $i$ voprosy francuzskogo yazyka [General linguistics and questions of the French language]. Moskva: Inostr. lit-ra [in Russian]. 2. Beloshapkova, V. A. (1970). Predlozheniya al'ternativnoj motivacii v sovremennom russkom yazyke [Alternative motivation suggestions in modern Russian]. In Issledovaniya po sovremennomu russkomu yazyku - Studies in modern Russian language (s. 13-32). Moskva: Izd-vo Mosk. un-ta [in Russian]. 3. Vinogradov, V. V. (Red.). (1954). Grammatika russkogo yazyka [Russian grammar]. (Vol. 2). Moskva: Izd-vo AN SSSR [in Russian]. 4. Vykhovanets, I. R. (1993). Hramatyka ukrainskoi movy. Syntaksys [Grammar of the Ukrainian language. Syntax]. Kyiv: Lybid [in Ukrainian]. 5. Gizatulin, S. L. (2001). Semanticheskaya e'konomiya i izbytochnost' $\mathrm{v}$ rechi [Semantic economy and redundancy in speech]. Filologicheskie nauki - Philological sciences, 2, 75-84. [in Russian]. 6. Horodenska, K. (2007). Hramatychnyi slovnyk ukrainskoi movy: Spoluchnyky [Grammar dictionary of the Ukrainian language: Conjunctions]. Kherson: KhDU [in Ukrainian]. 7. Dimitrova, S. (1985). Aktualizaciya predlozheniya i ee zavisimost' ot stepeni osvedomlennosti adresata [Actualization of the proposal and its dependence on the degree of awareness of the addressee]. Novoe v zarubezhnoj lingvistike. Sovremennaya zarubzhenaya russistika - New in foreign linguistics. Modern hackneyed Russian studies. (Iss. 15). (pp. 540-563). Moskva: Progress [in Russian]. 8. Zahnitko, A. P. (2001). Teoretychna hramatyka ukrainskoi movy: Syntaksys [Theoretical grammar of the Ukrainian language: Syntax]. Donetsk: DonNU [in Ukrainian].

9. Zaoborna, M. S. (1996). Skladnopidriadni porivnialni rechennia v suchasnii ukrainskii movi [Complex comparative sentences in the modern Ukrainian language]. Candidate's thesis. Ternopil: Ternop. derzh. ped inst. [in Ukrainian]. 10. Kolosova, T. A. (1980). Russkie slozhnye predlozheniya asimmetrichnoj struktury [Russian complex sentences of asymmetric structure]. Voronezh: Izd-vo Voronezh. un-ta [in Russian]. 11. Kulbabska, O. V. (2011). Vtorynna predykatsiia u prostomu rechenni [Secondary predication in a simple sentence]. Chernivtsi: Cherniv. nats. un-t [in Ukrainian]. 12. Kul'kova, R. A. (1994). Semanticheskie tipy predlozhenij s soyuzom Esli by [Semantic types of sentences with conjunction Если бы]. Sistemnyj analiz znachimyx edinic ruskogo yazyka. Smyslovye tipy predlozhenij - Systematic analysis of significant units of the Russian language. Semantic sentence types. (P. I). (pp. 149156). Krasnoyarsk: Krasnoyar. gos. un-t [in Russian]. 13. Lomakovych, S. V. (1993). Zaimennykovo-spivvidnosni rechennia v suchasnii ukrainskii movi [Pronoun-relative 
sentences in the modern Ukrainian language]. Doctor's thesis. Ternopil: Ternop. derzh. ped inst. [in Ukrainian]. 14. Norman, B. Yu. (2013). Kognitivnyj sintaksis russkogo yazyka [Cognitive syntax of the Russian language]. Moskva: FLINTA [in Russian]. 15. Slynko, I. I., Huivaniuk, N. V., \& Kobylianska, M. F. (1994). Syntaksys suchasnoi ukrainskoi movy: Problemni pytannia [Syntax of the modern Ukrainian language: Problematic issues]. Kyiv: Vyshcha shk. [in Ukrainian]. 16. Shytyk, L. (2014). Synkhronna perekhidnist syntaksychnykh odynyts $v$ ukrainskii literaturnii movi [Synchronous transition of syntactic units in the Ukrainian literary language]. Cherkasy: Vyd. Chabanenko Yu. A. [in Ukrainian].

Полозова Олена Олександрівна - кандидат філологічних наук, доцент кафедри українознавства і лінгводидактики, Харківський національний педагогічний університет імені Г. С. Сковороди; вул. Валентинівська, 2, м. Харків, 61168, Україна.

Tel.: +38-097-819-06-57

E-mail: polozoval@ukr.net

http://orcid.org/0000-0002-6780-1764

Polozova Olena Oleksandrivna - Candidate of Philological Sciences (Ph.D.), Associate Professor at the Department of Ukrainian Studies and Linguistic Didactics, H. S. Skovoroda Kharkiv National Pedagogical University; 2 Valentynivska Str., Kharkiv, 61168, Ukraine.

Надійшла до редакції 3 вересня 2021 року

\section{CITATION}

ДСТУ 8302:2015: Полозова О. О. Імпліцитний диктум як чинник формування кількісно асиметричних складних сполучникових речень. Лінгвістичні дослідження: зб. наук. пр. Харк. нац. пед. ун-ту імені Г. С. Сковороди. Харків, 2021. Вип. 55. С. 33 48. DOI: https://doi.org/10.34142/23127546.2021.55.04

APA: Полозова, О. О. (2021). Імпліцитний диктум як чинник формування кількісно асиметричних складних сполучникових речень. Лінгвістичні дослідження, 55, 33-48. DOI: https://doi.org/10.34142/23127546.2021.55.04 